\title{
ANALISIS KEPERCAYAAN DIRI (SELF-CONFIDENCE) SISWA DALAM PEMBELAJARAN MATEMATIKA MELALUI MODEL PROBLEM BASED LEARNING
}

\author{
Zuhur Fardani ${ }^{1}$, Edy Surya ${ }^{2}$, Mulyono $^{2}$
}

\begin{abstract}
ABSTRAK
Penelitian ini bertujuan untuk menganalisis sikap Kepercayaan diri (self confidence) siswa setelah pelaksanaan model Problem Based Learning. Penelitian ini merupakan penelitian kualitatif deskriptif. Subjek penelitian ini adalah siswa MAS Al-Washliyah Km. 6 Medan, Kelas XI-A yang berjumlah 30 orang. Kemudian dipilih subjek wawancara berdasarkan kategori kecerdasan logis matematis dan pola jawaban yang dominan pada setiap kategori. Adapun hasil penelitian sebagai berikut: (1) Kepercayaan diri (self confidence) siswa setelah diterapkan model problem based learning didapat bahwa dari 30 siswa terdapat 6 siswa yang memiliki keepercayaan diri (self confidence) kategori tinggi, 20 siswa yang memiliki kategori sedang, dan 4 siswa yang memiliki kategori rendah. (2) Kesulitan siswa dalam menyelesaikan tes kecerdasan logis matematis siswa a) pada kategori tinggi dan sedang, siswa mengalami kesulitan pada kategori pemecahan masalah; b) pada kategori rendah, siswa mengalami kesulitan pada kategori konsep dan pemecahan masalah.
\end{abstract}

Kata Kunci: Kepercayaan Diri Siswa, Self-Confidence, Model Problem Based Learning

\section{PEDAHULUAN}

Menurut Permendiknas nomor 22 tahun 2006, matematika adalah salah satu mata pelajaran yang dipelajari oleh siswa yang dimulai dari Sekolah Dasar, Sekolah Menengah bahkan sampai ke Perguruan Tinggi. Hal ini dimaksudkan untuk membekali siswa dengan berfikir logis, analitis, sistematis, kritis dan kreatif serta kemampuan bekerja sama (Harahap, 2017). Artinya, siswa diharapkan dapat menggunakan matematika dan pola pikir matematika dalam kehidupan sehari-hari dan dalam mempelajari berbagai ilmu pengetahuan yang penekanannya pada penataan nalar, pembentukan sikap siswa serta ketrampilan dalam penerapan matematika. Untuk siswa dalam pembelajaran matematika diharapkan tidak menghafal rumus, konsep, dan prosedur yang diajarkan tetapi memahami konsep tersebut dan tahu darimana rumus itu didapat.

Coockroft (Abdurrahman, 2009: 253) mengemukakan beberapa alasan mengapa matematika harus diajarkan kepada siswa, seperti: (1) selalu digunakan dalam semua aspek kehidupan; (2) semua bidang studi membutuhkan keterampilan matematika yang sesuai; (3) adalah sarana komunikasi yang kuat, jelas dan ringkas; (4) dapat digunakan untuk menyajikan informasi dalam berbagai cara; (5) meningkatkan kemampuan berpikir logis, akurasi dan kesadaran spasial; (6) memberi kepuasan pada upaya memecahkan tantangan masalah. Ini sejalan dengan tujuan pembelajaran matematika menurut kurikulum

\footnotetext{
${ }^{1}$ Corresponding Author: Zuhur Fardani

Guru MAS Al-Washliyah Km. 6 Medan, Medan, 20241, Indonesia E-mail: zhuzfd@gmail.com

${ }^{2}$ Co-Author: Edy Surya \& Mulyono

Program Studi Pendidikan Matematika Universitas Negeri Medan, Medan, 20221, Indonesia
}

2013 (Kemendikbud, 2013) adalah (1) meningkatkan kemampuan intelektual, khususnya kemampuan tingkat tinggi siswa, (2) membentuk kemampuan siswa dalam menyelesaikan suatu masalah secara sistematik, (3) memperoleh hasil belajar yang tinggi, (4) melatih siswa dalam mengomunikasikan ide-ide, khususnya dalam menulis karya ilmiah, dan (5) mengembangkan karakter siswa.

Walau pun matematika merupakan pelajaran yang berdaya guna tinggi, namun sebagian besar siswa masih kurang termotivasi dalam belajar matematika. Mereka masih beranggapan bahwa matematika merupakan pelajaran yang sulit, sukar, dan menegangkan. Hal ini didukung dengan sebagian besar guru matematika yang berpenampilan kurang familiar atau tertalu serius. Sehingga motivasi belajar siswa dalam mempelajari matematika kurang optimal. Hasil belajar matematika siswa dipengaruhi oleh faktor internal dan faktor ekternal. Faktor internal merupakan faktor yang berasal dari dalam diri siswa sendiri, seperti : motivasi, kecerdasan emosional, kecerdasan matematis-logis, rasa percaya diri, kemandirian, sikap dan lain-lain. Sedangkan faktor eksternal merupakan faktor yang berasal dari luar diri siswa, seperti : sarana dan pra sarana, lingkungan, guru, kurikulum, dan metode mengajar.

Simmers (Surya, 2017) mengatakan bahwa matematika sering mengalami kesulitan. Ini terlihat dari hasil studi PISA tahun 2018 (OECD, 2018) dimana Indonesia menempati peringkat 75 dari 80 negara peserta, atau dengan kata lain menempati peringkat keenam terbawah dari seluruh negara peserta PISA yang disurvey dengan rata-rata kemampuan matematika siswa Indonesia yaitu 379, sekor tersebut di bawah rata-rata skor internasional yaitu 458,3. Siswa Indonesia masih sering mengalami kesulitan dalam menyelesaikan soal matematika. 
Vol. 14, No. 1, Juni 2021

Hasil penelitian dari Rohayati dan Surdita (Eviyanti, 2017), menyatakan bahwa kurang dari 50\% siswa masih kurang percaya diri dengan gejala seperti merasa malu kalau disuruh ke depan kelas, perasaan tegang dan takut yang tiba-tiba datang pada saat tes, siswa tidak yakin akan kemampuannya sehingga berbuat mencontek padahal pada dasarnya siswa telah mempelajari materi yang diujikan, serta tidak bersemangat pada saat mengikuti pelajaran di kelas dan tidak suka mengerjakan pekerjaan rumah. Hasil penelitian Novferma (2016) menyatakan bahwa faktorfaktor kesulitan yang dialami siswa dalam menyelesaikan soal matematika yaitu siswa merasa waktu yang diberikan tidak cukup, mudah menyerah, kurang teliti, sering lupa, merasa cemas, dan siswa tergesa-gesa untuk mengerjakan soal. Peristiwa ini terlihat jelas oleh peneliti saat melakukan observasi di MAS Al-Washliyah KM. 6 Pulo Brayan Medan.

Salah satu faktor internal yang mempengaruhi pembelajaran adalah kecerdasan. Salah satu kecerdasan yang berkaitan dengan kemampuan pemecahan masalah adalah kecerdasan logis matematis. Kecerdasan logis matematis meliputi perhitungan matematis, berpikir logis, pemecahan masalah, penalaran induktif dan penalaran deduktif, serta ketajaman dalam pola dan hubungan. Dengan adanya unsur pemecahan masalah pada kecerdasan logis matematis, tentunya akan berpengaruh pada prestasi belajar matematika siswa.

Kecerdasan logis matematis rnerupakan hal yang cukup penting bagi siswa dan guru. Bagi siswa, dapat mendorong semangat siswa berprestasi dalam belajar dan mengarahkan kegiatan belajar sesuai dengan kebutuhannya. Sedangkan bagi guru, dengan memahami dan mengetahui kecerdasan logis siswa maka guru akan dapat membangkitkan, meningkatkan, dan memelihara semangat siswa untuk berhasil dalam belajar, mampu menyesuaikan strategi mengajarnya sesuai dengan kondisi siswa, dan mampu mendudukkan posisinya dalam kegiatan pembelajaran.

Selain kecerdasan logis matematis, ada hal penting lainnya yang harus diperhatikan yaitu aspek psikologi siswa yang dapat mempengaruhi keberhasilan siswa dalam menyelesaikan setiap permasalahan matematika. Aspek psikologi yang dimaksud adalah self confidence siswa. Self confidence menjadi aspek yang cukup berpengaruh terhadap keberhasilan siswa, karena self confidence itu sendiri merupakan kepercayaan diri dalam melakukan tugas dan memilih cara penyelesaian yang baik, tepat dan efektif.

Sikap postif matematika perlu diperhatikan, karena tumbuhnya sikap positif pada diri siswa diyakini akan tumbuh juga semangat terhadap matematika. Hal ini sejalan dengan Ruseffendi (Purwasih, 2015:19) mengatakan bahwa sikap positif terhadap matematika berkorelasi positif dengan prestasi belajar matematika.

Selanjutnya Hannula, Maijah \& Pohkonen (Purwasih, 2015:19) menyatakan bahwa jika siswa memiliki self confidence yang baik, maka siswa dapat sukses dalam belajar matematika. Oleh karena itu, self confidence mampu mendukung motivasi dan kesuksesan siswa dalam belajar matematika. Siswa akan cenderung memahami, menemukan, dan memperjuangkan masalah matematika yang dihadapinya untuk solusi yang diharapkan.

Menurut Lauster (Muniro, dkk, 2018) mengatakan "bahwa Self-Confidence (kepercayaan diri) adalah sikap atau keyakinan atas kemampuan diri yang terdapat pada diri seseorang sehingga orang yang besangkutan tidak cemas dalam tindakan atau perbuatannya, merasa bebas melalukan segala hal yang diminatinya, dan bertanggung jawab". Self-Confidence (kepercayaan diri) juga dapat memberikan motivasi terhadap pencapaian suatu keberhasilan seseorang dalam menyelesaiakan permasalahannya. "Sehingga semakin tinggi self-confidence (kepercayaan diri) seseorang terhadap kemampuan diri yang dimiliki akan semakin kuat/tinggi pula seseorang dalam menyelesaikan pekerjaannya atau permasalahannya". Hendriana (Tresnawati, Hidayat, \& Rohaeti, 2017).

Menurut Sidik, Ramlah, \& Utami (2017) "jika seseorang mempunyai self-confidence (kepercayaan diri) yang baik atau tinggi, maka individu tersebut akan baik pula akan dan akan menjadikan keberhasilan dalam seseorang terutama dalam hal pembelajaran. Artinya jika self confidence (kepercayaan diri) siswa baik, maka ia akan menjadi sukses didalam proses pembelajaran yang dilakukan. Seorang siswa akan berhasil didalam proses pembelajaran disekolah jika siswa tersebut dapat mencapai tujuan pembelajaran."

Menurut TIMSS (Purwasih, 2015:68) menunjukkan bahwa self confidence siswa Indonesia masih rendah dibawah $30 \%$. Self confidence menurut TIMMS yaitu memiliki matematika yang baik, mampu belajar matematika dengan cepat dan pantang menyerah, menunjukan rasa yakin dengan kemampuan matematika yang dimilikinya, dan mampu berfikir secara realistik. Dengan demikian, dapat disimpulkan bahwa self confidence penting untuk dimiliki oleh siswa. Melalui kerja kelompok atau diskusi, self confidence dapat dikembangkan, di sini siswa dituntut untuk mampu mengeksplorasi dan menemukan sendiri konsep-konsep matematika yang sedang dipelajarinya.

Menurut Basavanna (Istiawati, 2017), "Self confidence refers to an individual's preceived ability to act effetively in a situation to overcome obstacles and to get things go all right". Bermakna bahwa self convidence mengacu pada individu yang memiliki kemampuan untuk bertindak secara efektif dalam situasi untuk mengatasi hambatan dan untuk mendapatkan sesuatu yang baik.

Siswa yang memiliki kepercayaan diri dapat menyelesaikan tugas atau pekerjaan yang sesuai dengan kemampuan yang dimilikinya, maka hal ini akan berdampak positif terhadap dirinya sehingga siswa menjadi lebih yakin dan dapt meningkatkan prestasi yang diperoleh. Rasa percaya diri siswa dalam belajar matematika di Indonesia masih rendah. Hal ini sesuai dengan yang dikemukakan Rohayati (Istiawati, 2017) bahwa kurang dari 50\% siswa masih kurang 
percaya diri dengan gejala seperti siswa meras malu jika diminta ke depan kelas, perasaan tegang dan takut yang tiba-tiba datang saat tes, siswa tidak yakin akan kemampuannya sehingga berbuat mencontek padahal pada dasarnya siswa telah mempelajari materi yang diujikan, serta tidak bersemangat pada saat mengikuti pelajaran di kelas dan tidak suka mengerjakan pekerjaan rumah.

Untuk menguasai kompetensi yang dituntut pada mata pelajaran matematika sangat diperlukan proses pembelajaran matematika yang diarahkan pada kegiatan-kegiatan yang mendorong siswa aktif belajar baik fisik, mental intelektual, maupun sosial untuk memahami konsep-konsep matematika. Hal ini berarti guru dituntut untuk menggunakan strategi yang melibatkan siswa aktif dalam belajar sehingga dapat mengaktifkan interaksi antara siswa dan guru. Tampaknya masih ada kesenjangan yang cukup besar antara apa yang diharapkan dalam proses belajar matematika dengan kenyataan yang dicapai. Sedangkan menurut Biyarti (2013) seorang guru yang profesional harus dapat menjadi fasilitator, motivator dan agen pembelajaran yang baik bagi setiap siswanya. Keberhasilan seorang guru dalam mendidik dan membimbing siswa untuk dapat menguasai matematika salah satu tolak ukurnya adalah tercapainya tujuan pembelajaran yaitu bahwa siswa dapat menguasai standar kompetensi dan kompetensi dasar yang dituliskan dalam rencana pembelajaran yang dirancang guru.

Salah satu usaha guru untuk memperbaiki proses pembelajaran adalah dengan memilih model pembelajaran yang tepat dan inovatif dalam pembelajaran matematika. Namun kenyataan di lapangan berdasarkan hasil wawancara dengan guru matematika di MAS Al-Washliyah Km.6 Medan, guru masih menggunakan model pembelajaran konvensional saat mengajar yang membuat pembelajaran kurang bermakna. Artinya, dalam proses pembelajaran siswa tidak mengalami sendir begaimana proses matematika. Guru masih menganut paradigma transfer of knowledge dalam pembelajaran, dimana guru sekedar mentransfer ilmunya dan tidak memberi kesempatan siswa untuk mengeksplorasi kemampuan matematika yang mereka miliki sehingga siswa terkadang tidak diberikan kesempatan untuk mengembangkan kemampuan yang mereka miliki. Proses pembelajaran yang demikian membuat siswa kurang aktif selama proses pembelajaran, hal ini dikarenakan siswa hanya menerima ilmu yang diberikan oleh guru tanpa mengalami proses.

Matematika sekolah menurut Ebbut dan Straker (Sutama, 2011) memiliki empat karakteristik, yakni sebagai: (1) kegiatan penelusuran pola dan hubungan; (2) kreativitas yang memerlukan imajinasi, intuisi dan penemuan; (3) kegiatan pemecahan masalah (problem solving); dan (4) alat berkomunikasi. Dari pernyataan Ebbut dan Straker, karakteristik matematika sekolah tersebut menuntut guru untuk kreatif dan antisipatif terhadap keefektifan pembelajaran matematika disekolah. Pada kenyataannya guru belum mampu menunjukkan karakteristik matematika tersebut di dalam proses pembelajaran matematika di sekolah. Ansari (2016) menjelskan tentang kondisi sekolah dalam proses pembelajaran matematika, yaitu: (a) Dalam mengajar guru sering mencontohkan pada siswa bagaiman menyelesaikan soal; (b) siswa belajar dengan cara mendengarkan dan menonton guru melakukan matematik, kemudian guru mencoba memecahkan sendiri; dan (c) pada saat mengajar matematika, guru langsung menjelaskan dengan pemberian contoh, dan soal untuk latihan.

Kondisi diatas menggambarkan pembelajaran yang terlaksana adalah pembelajaran yang berpusat pada guru, guru mendominasi pembelajaran sehingga keterlibatan siswa dalam proses pembelajaran masih sangat kurang. Akibat dari kondisi sekolah dalam proses pembelajaran matematika menunjukkan keterbatasan guru untuk menghadirkan karakteristik dari matematika sehingga kemampuan-kemampuan yang diharapkan untuk siswa mampu mengahadapi perkembangan IPTEK, tidak diperoleh.

Pembelajaran yang baik adalah pembelajaran yang mengembangkan cara siswa belajar aktif dalam prosesnya. Pernyataan tersebut sesuai dengan pendapat Chrissanti dan Widjajanti (Simatupang, 2019:15) yang menyatakan bahwa siswa harus mampu berinisiatif dan melibatkan dirinya secara aktif dalam mempelajari matematika. Dengan demikian akan timbul suatu interaksi yang baik antara guru dan siswa dalam proses pembelajaran, sehingga siswa bukan lagi menjadi objek pembelajaran tetapi pusat kegiatan pembelajaran.

Menyikapi hal tersebut, banyak model pembelajaran inovatif telah diterapkan dalam pembelajaran matematika. Salah satu model pembelajaran yang disarankan dalam pelaksanaan kurikulum 2013 adalah model Problem Based Learning (PBL). Model PBL memiliki karakteristik yaitu: (1) belajar dimulai dengan suatu masalah, (2) memastikan bahwa masalah yang diberikan berhubungan dengan dunia nyata siswa, (3) mengorganisasikan pelajaran diseputar masalah, bukan diseputar disiplin ilmu, (4) memberikan tanggung jawab yang besar kepada pembelajar dalam membentuk dan menjalankan secara langsung proses belajar mereka sendiri, (5) menggunakan kelompok kecil, dan (6) menuntut pembelajar untuk mendemontrasikan apa yang telah mereka pelajari dalam bentuk suatu produk atau kinerja (Ngalimun, 2013).

Akan tetapi, dalam prakteknya model problem based learning masih menemui kendala seperti: masih banyak siswa yang kesulitan memahami masalah, siswa masih sulit dalam melakukan penyelidikan secara individu maupun kelompok untuk konsep-konsep yang abstrak, serta siswa mengalami kesulitan menentukan penyelesaian masalah yang diberikan. Pada kenyataanya sulit untuk diterapkan begitu saja tanpa persiapan, baik dari segi perumusan masalah itu sendiri, tindakan guru untuk memfasilitasi siswa, maupun pola pikir siswa yang efektif untuk dapat memecahkan masalah matematika dengan baik (Ngalimun, 2013). 
Adapun hubungan problem based learning (PBL) terhadap kecerdasan logis bisa kita lihat dari beberapa hasil penlitian berikut ini. Efektifitas PBL dibuktikan oleh Prayogi (Putra, 2019), dalam penelitiannya yang berjudul Implementasi Model PBL (Problem Based Learning) untuk Meningkatkan Hasil Belajar dan Kemampuan Berpikir Kritis Siswa. Simpulan penelitian ini yaitu implementasi model PBL (Problem Based Learning) dapat meningkatkan hasil belajar dan kemampuan berpikir kritis siswa. Data yang diambil dari observasi yang dilakukan di SMP Muhammadiyah Aimas bulan September 2017 (Astutik, 2019) menunjukan bahwa SMP Muhammadiyah Aimas masih menggunakan Kurikulum Tingkat Satuan Pendidikan (KTSP) 2006 dengan tingkat ketuntasan nilai matematika khususnya kelas VIII masih sangat rendah, dari 20 siswa yang ada dikelas hanya 1-2\% yang memenuhi nilai ketuntasan minimal.

Adapun hubungan problem based learning (PBL) terhadap self confidence bisa dilihat pada penelitian yang dilakukan Syaifatunnisa (Istawati, 2017) menyimpulkan bahwa siswa sebelumnya terbiasa menerima pembelajaran dengan hanya mendengar penjelasan dari guru. Namun, hasil penelitiannya menunjukkan hasil yang positif dalam penggunaan model problem based learning (PBL). Hal ini dapat terlihat, dengan menggunakan model problem based learning mereka belajar untuk mengemukakan pendapat dan jawaban kelompoknya di depan kelas dan berani memberi pertanyaan dan tanggapan. Dengan demikian setelah penerapan model problem based learning, self confidence matematis siswa meningkat.

Berdasarkan uraian di atas, peneliti termotivasi untuk melakukan penelitian dengan judul "Analisis Kepercayaan Diri Self-Confidence Siswa Dalam Pembelajaran Matematika Melalui Model Problem Based Learning".

\section{KAJIAN TEORI}

\section{Pengertian Model Pembelajaran}

Pendekatan pengajaran dengan konten pembelajaran pengalaman yang kuat, mendorong pembelajaran yang mendalam dan memberikan hasil belajar yang unggul (Kolb, 2015). Oleh sebab itu model pembelajaran sangat berperan dalam aktivitas belajar mengajar, dimana guru dapat memilih model yang tepat untuk sebuah materi.

Strategi menurut Kemp (Rusman, 2012:132) adalah kegiatan pembelajaran yang harus dikerjakan guru dan siswa agar tujuan pembelajaran dapat dicapai secara efektif dan efesien.

Joyce dan Weil (Rusman, 2012:133) berpendapat bahwa model pembelajaran adalah suatu rencana atau pola yang dapat digunakan untuk membentuk kurikulum (rencana pembelajaran jangka panjang), merancang bahan-bahan pembelajaran, dan membimbing pembelajaran di kelas atau yang lain.

Model pembelajaran dapat mendiskripsikan prosedur dalam mengorganisasikan pengalaman belajar peserta didik untuk mencapai tujuan belajar tertentu.
Model pembelajaran juga sebagai pedoman dan acuan bagi para guru untuk mendesain kegiatan pembelajaran yang ingin dilaksanakan.

\section{Model Problem Based Learning (PBL)}

Menurut Dewey (Trianto, 2011:91) belajar berdasarkan masalah adalah interaksi antara stimulus dengan respons, merupakan hubungan antara dua arah belajar dan lingkungan. Dimana lingkungan sangat berperan terhadap proses belajar siswa. Lingkungan memberikan stimulus kepada siswa berupa bantuan bagaimana menyelesaikan masalah dan juga memberi masalah baru untuk diselesaikan.

Margetson (Rusman, 2011:230) mengatakan bahwa model pembelajaran berbasis masalah (Problem Based Learning) membantu untuk meningkatkan prkembangan keterampilan belajar sepanjang hayat dalam pola pikir yang terbuka, reflektif, kritis, dan belajar aktif, serta memfasilitasi keberhasilan memecahkan masalah, komuniksi, kerja kelompok, dan keterampilan interpersonal dengan lebih baik dibanding model lain. Pernyataan margeston ini diperkuat dengan pernytaan Boud dan Feletti (Rusman, 2011:230) yang menyatakan bahwasannya model pembelajaran berbasis masalah (Problem Based Learning) adalah inovasi yang paling signifikan dalam dunia pendidikan.

Problem Based Learning (PBL) adalah metode yang efisien dalam memfasilitasi pengembanagan keterampilan belajar mandiri melalui strategi pemecahan masalah terstruktur (D. Centea, 2017).

Problem Based Learning berfokus pada pengalaman pembelajaran yang terorganisasi dengan mencari dan menyelesaikan masalah-masalah yang ada di dunia nyata (Linda dan Sara, 2002:15).

Arends (2008b:41) menyatakan bahwa model pembelajaran berbasis masalah merupakan suatu model pembelajaran dimana siswa mengerjakan permasalahan yang autentik dengan maksud untuk menyusun pengetahuan mereka sendiri, mengembangkan inkuiri dan keterampilan berpikir tingkat lebih tinggi lagi, mengembangkan kemandirian dan percaya diri. Diperkuat dengan pernyataan Tan (Rusman, 2011:232) yang menyatakan bahwa pembelajaran berbasis masalah merupakan penggunaan berbagai macam kecerdasan yang diperlukan untuk melakukan konfrontasi terhadap tantangan dunia nyata, kemampuan untuk menghadapi segala sesuatu yang baru dan kompleksitas yang ada.

Menurut Pehkonen (2007), "problem solving has been one of the general goals overall in the finnish curriculum". Menurut Pehkonen pemecahan masalah telah menjadi salah satu tujuan umum secara keseluruhan dari kurikulum Finlandia.

Menurut Polya (Eviyanti, 2017) ada empat tahap dalam menyelesaikan masalah; (1) memahami masalah: di kegiatan ini kita mencari tahu apa yag diketahui, apa yang ditanya, apakah informasinya cukup, syarat apa yang harus dipenuhi, lalu menyatakan kembali informasi yang ada secara lebih operasional. (2) merencanakan solusi; (3) 
Vol. 14, No. 1, Juni 2021

melaksanakan pemecahan masalah; (4) mengevaluasi

kembali hasil pemecahan masalah.

\section{Kepercayaan Diri (Self Confidence)}

Selain kecerdasan logis matematis, kemampuan disposisi matematika juga sangatlah penting. Pentingnya pengembangan disposisi matematis sesuai dengan pernyataan Sumarmo (2013:334) bahwa dalam pembelajaran matematika pembinaan komponen ranah afektif memerlukan kemandirian yang kemudian akan membentuk kecenderungan yang kuat yang dinamakan pula disposisi matematik (mathematical disposition) yaitu keinginan, kesadaran, dedikasi, dan kecenderungan yang kuat pada diri siswa untuk berpikir dan berbuat secara matematik dengan cara yang positif dan didasari dengan iman, taqwa, dan akhlak mulia.

Menurut Polking (Hidayat, 2013:104) sikap disposisi dapat dirumuskan dalam beberapa indikator yaitu: a) rasa percaya diri dalam menggunakan matematika, memecahkan masalah, memberi alasan dan mengkomunikasikan gagasan; b) fleksibilitas dalam menyelidiki gagasan matematik dan berusaha mencari metoda alternatif dalam memecahkan masalah; c) tekun mengerjakan tugas matematik; d) minat, rasa ingin tahu, dan daya temu dalam melakukan tugas matematik; e) cenderung memonitor, merefleksikan penampilan dan penalaran mereka sendiri; f) menilai aplikasi matematika ke situasi lain dalam matematika dan pengalaman sehari-hari; g) memberikan apresiasi peran matematika dalam kultur dan nilai, matematika sebagai alat, dan sebagai bahasa.

Senada dengan pernyataan Polking, Silver (Sumarmo, 2013:203) menguraikan disposisi matematik dalam beberapa komponen yaitu: rasa percaya diri (self confident), rasa diri mampu (self efficacy), rasa ingin tahu (curiousity), senang mengerjakan tugas matematik, rajin dan tekun (deligence), fleksibel (flexibility), dan reflektif.

Siswa membutuhkan disposisi yang akan menjadikan mereka gigih menghadapi masalah yang lebih menantang dan bertanggung jawab terhadapa belajar mereka sendiri, serta untuk mengembangkan kebiasaan baik di matematika. Itu sebabnya disposisi matematis termasuk salah satu faktor yang ikut menentukan keberhasilan belajar siswa.

Dalam proses belajar mengajar, disposisi matematis dapat dilihat dari keinginan siswa untuk merubah strategi, melakukan refleksi, dan melakukan analisis sampai memperoleh suatu solusi atas masalah yang ia hadapi. Disposisi siswa terhadap matematika dapat diamati dalam diskusi kelas. Misalnya, seberapa besar keinginan siswa untuk belajar matematika, keinginan menjelaskan solusi yang diperolehnya dan mempertahankan penjelasannya. Namun demikian, perhatian guru dalam proses belajar-mengajar terhadap disposisi matematis siswa masih kurang. Oleh sebab itu ketertarikan siswa untuk menyelesaikan masalah juga kurang.
Pengaruh faktor diri (self) terhadap kemampuan matematika peserta didik diungkapkan oleh Ma \& Kishor (Wulandari, 2017) bahwa there is a positive interaction between mathematics attitude and mathematics achievement. There is also a positive relationship between self-concept about mathematics. Artinya terdapat hubungan yang positif antara konsep dir tentang matematika dengan prestasi matematika. Konsep diri tentang matematika yang dimaksud adalah sikap percaya diri dalam belajar matematika, gemar akan matematika, dan percaya akan kegunaan matematika. Maka dari itu, diperlukan suatu pembelajaran matematika yang dapat melibatkan peserta didik secara aktif dan dapat merangsang tumbuhnya kepercayaan diri peserta didik agar peserta didik dapat memperoleh hasil belajar matematika secara optimal.

Self confidence bukan merupakan sesuatu yang sifatnya bawaan tetapi merupakan sesuatu yang terbentuk dan interaksi. Untuk menimbulkan self confidence diperlukan situasi yang memberikan kesempatan untuk berkompetisi, karena seseorang belajar tentang dirinya sendiri melalui interaksi langsung dan komparasi sosial. Dari interaksi langsung dengan orang lain akan diperoleh informasi tentang diri dan dengan melakukan komparasi sosial seseorang dapat menilai dirinya sendiri bila dibandingkan dengan orang lain. Sesorang akan dapat memahami diri sendiri dan akan tahu siapa dirinya yang kemudian akan berkembang menjadi percaya diri atau self confidence.

Orang yang percaya diri atau self confidence memiliki sikap yang tenang dan bersikap positif dalam menghadapi berbagai masalah dan tidak mudah menyerah, memiliki kemampuan sosialisasi yang baik, percaya kepada kemampuan sendiri, berani mengungkapkan pendapat, tidak mementingkan diri sendiri melaksanakan tugas dengan baik dan bertanggung jawab serta mempunyai rencana terhadap masa depannya. Dengan kemampuan-kemampuan tersebut individu mempunyai kemugkinan untuk lebih sukses dalam menjalani kehidupan bila dibandingkan dengan orang yang kurang atau tidak percaya diri atau self confidence rendah.

Berdasarkan uraian di atas maka dapat disimpulkan bahwa self confidence adalah perasaan yakin akan kemampuan sendiri yang mencakup penilaian dan penerimaan yang baik terhadap dirinya secara utuh, bertindak sesuai dengan apa yang diharapkan oleh orang lain sehingga individu dapat diterima oleh orang lain maupun lingkungannya. Penerimaan ini meliputi penerimaan secara fisik dan psikis. Berdasarkan pendapat di atas dapat disimpulkan bahwa self confidence merupakan adanya sikap individu yakin akan kemampuannya sendiri untuk bertingkah laku sesuai dengan yang diharapkannya sebagai suatu perasaan yang yakin pada tindakannya, bertanggung jawab terhadap tindakannya dan tidak terpengaruh oleh orang lain. Orang yang memiliki kepercayaan diri mempunyai ciri-ciri: toleransi, tidak memerlukan dukungan orang lain dalam setiap mengambil 
Vol. 14, No. 1, Juni 2021

keputusan atau mengerjakan tugas, selalu bersikap optimis dan dinamis, serta memiliki dorongan prestasi yang kuat.

\section{Kesulitan Belajar Matematika}

Kesulitan belajar adalah suatu keadaan yang menyebabkan siswa tidak dapat belajar sebagaimana mestinya. Menurut Sabri (dalam Widdiharto, 2008:3) kesulitan belajar yaitu kesukaran siswa dalam menerima atau menyerap pelajaran di sekolah. Kesulitan belajar adalah suatu kondisi dimana kompetensi atau prestasi yang dicapai tidak sesuai dengan kriteria standar yang telah ditetapkan.

Kesulitan belajar sering dialami oleh setiap siswa. Beberapa tanggapan dari siswa pada saat menanyakan dari berbagai studi diajarkan disekolah, matematika merupakan studi yang dianggap paling sulit oleh para siswa, baik yang tidak berkesulitan belajar dan lebihlebih bagi siswa yang berkesulitan belajar (Hodiyah, 2009:3). Hal tersebut menunjukkan bahwa ada siswa yang kesulitan belajar juga semakin menegaskan bahwa banyak siswa yang menganggap bahwa matematika itu sulit.

Damerow (1984:6) mengatakan bahwa adanya kesalahpahaman meningkatkan kesulitan yang melekat dalam matematika, seperti perwujudan matematika dalam situasi konkret yang sulit dipahami bagi banyak siswa. Di sisi lain, telah ditemukan bahwa anak-anak yang gagal di sekolah tetap dapat melakukan kegiatan matematika yang otentik

Siswa dengan kemampuan matematika tinggi, sedang, dan rendah ketika membaca soal masih terbilang lamban, banyak kata-kata yang hilang (Kania: 2017:68) . Siswa dengan kemampuan matematika sedang dan rendah masih kesulitan dan belum lancar dalam hal menambah, mengurang, membagi, dan mengalikan angka. Proses belajar matematika yang dirasa siswa kurang menyenangkan dikuatkan dengan pernyataan guru bahwa memang selama ini belum mengguankan model pembelajaran yang bervariasi dan yang tepat, dikarenakan masih kesulitan dalam penggunaan dan penerapannya.

Hughes (2003:113) mengemukakan masalah yang mungkin terjadi dalam kesulitan anak-anak dengan aritmatika. Pertama kita akan melihat kesulitan siswa untuk memahami operasi dalam matematika yang dikemukan dalam soal yang tidak nyata dan soal yang nyata (konkret). Kedua kita akan melihat kesulitan siswa dalam mencari cara dalam memecahkan masalah yang ada. Dan yang ketiga kita akan melihat bagaimana siswa merepresentasikan masalah tersebut.

Agar dapat membantu anak berkesulitan belajar matematika, guru perlu memahami berbagai kesalahan umum yang dilakukan anak dalam menyelesaikan tugas-tugas matematika. Menurut Lerner (dalam Widdiharto, 2008:6), kekurangan itu meliputi pemahaman tentang: simbol, nilai tempat, perhitungan, penggunaan proses yang keliru, dan tulisan yang tidak terbaca.
Berikut tabel yang menjelaskan indikator kesulitan menurut Lerner (dalam Made, 2015:4) yang sebagaimana disajikan pada Tabel berikut.

Tabel 1. Indikator Kesulitan dalam Menyelesaikan Soal

\begin{tabular}{cl}
\hline No. & \multicolumn{1}{c}{ Indikator } \\
\hline 1. & Kesulitan dalam mempelajari konsep \\
\hline 2. & Kesulitan dalam menerapkan keterampilan \\
\hline 3. & $\begin{array}{l}\text { Kesulitan dalam menyelesaikan pemecahan } \\
\text { masalah }\end{array}$ \\
\hline
\end{tabular}

(Made, 2015)

Lerner (dalam Abdurrahman, 2003:78) mengemukakan bahwa kurikulum bidang studi matematika hendaknya mencakup tiga elemen yaitu konsep, keterampilan dan pemecahan masalah. Untuk mengetahui kesulitan-kesulitan belajar matematika siswa, guru dapat menganalisis tes uraian yang dikerjakan siswa ditinjau dari penguasaan tiga elemen dalam studi matematika yang meliputi pemahaman konsep, keterampilan, dan pemecahan masalah.

Konsep menunjuk pada pemahaman dasar. Siswa mengembangkan suatu konsep ketika mereka mampu mengklasifikasikan atau mengelompokan benda-benda atau ketika mereka dapat mengasosiasikan suatu nama dengan kelompok benda tertentu, sebagai contoh anak mengenal konsep segitiga sebagai suatu bidang yang dikelilingi oleh tiga garis lurus. Menurut Darjiani (2015:1) indikator kesulitan-kesulitan matematika pada elemen konsep yaitu (1) kesulitan dalam menentukan rumus untuk menyelesaikan suatu masalah. (2) siswa dalam menggunakan rumus tidak sesuai dengan kondisi prasyarat berlakunya rumus tersebut atau tidak menuliskan rumus.

Keterampilan menunjuk pada sesuatu yang dilakukan oleh seseorang, sebagai contoh: proses dalam menggunakan operasi dasar dalam penjumlahan, pengurangan, perkalian dan pembagian adalah suatu jenis keterampilan matematika. Suatu keterampilan dapat dilihat dari kinerja anak secara baik atau kurang baik dan secara cepat atau lambat. Keterampilan cenderung berkembang dan dapat ditingkatkan melalui latihan. Menurut Darjiani (2015:1) indikator kesulitan matematika pada elemen keterampilan yaitu kesulitan menggunakan operasi dasar dalam penjumlahan, pengurangan, perkalian, pembagian, perhitungan akar dan kuadrat.

Pemecahan masalah adalah aplikasi dari konsep dan keterampilan.Dalam pemecahan masalah biasanya melibatkan beberapa kombinasi konsep dan keterampilan dalam suatu situasi baru atau situasi yang berbeda dari sebelumnya. Sebagai contoh, pada saat peserta diminta untuk mengukur luas selembar papan, beberpa konsep dan keterampilan ikut terlibat. Menurut Darjiani (2015:1) indikator kesulitan matematika dalam elemen pemecahan masalah yaitu siswa tidak dapat melanjutkan pekerjaannya dalam menyelesaikan soal serta faktor ekstern yang meliputi faktor guru dan faktor lingkungan.

Kebanyakan siswa masih mengalami kesulitan dalam menerapkan rumus-rumus, memahami teorema- 
Vol. 14, No. 1, Juni 2021

teorema, bahkan yang paling utama siswa masih mengalami kesulitan dalam memahami permasalahan dalam suatu soal matematika (Sholihah \& Afriansyah, 2017:151). Berdasarkan penelitian yang dilakukan Yeo (Sholihah \& Afriansyah, 2017:151) di Singapura yang meneliti tentang kesulitan yang dialami siswa kelas IX dalam memecahkan masalah matematika menyebutkan bahwa kesulitan yang dialami oleh siswa ketika memecahkan masalah matematika adalah kesulitan dalam: (a) memahami masalah yang diberikan (lack of comprehension of the problem posed), (b) menentukan strategi penyelesaian yang tepat (lack of comprehension of strategy knowledge), (c) membuat model matematika (inability to translet the problem into mathematical form), dan (d) melakukan prosedur matematika yang benar (inability to use the correct mathematics). Menurut Slameto (dalam Sholihah \& Afriansyah, 2017:151) "Kesulitan tersebut bisa disebabkan karena dua faktor : Faktor internal seperti jasmani, psikologi, dan kelelahan, dan faktor eksternal yaitu keluarga, sekolah, dan lingkungan masyarakat".

\section{METODE PENELITIAN \\ Jenis Penelitian}

Jenis penelitian yang digunakan dalam penelitian ini adalah penelitian deskriptif kualitatif. Denzim dan Lincoln (Moleong, 2017:5) menyatakan bahwa "Penelitian kualitatif adalah penelitian yang menggunakan latar alamiah, dengan maksud menafsirkan fenomena yang terjadi dan dilakukan dengan jalan melibatkan berbagai metode yang ada". Senada dengan hal tersebut Moleong (2017:6) mendefenisikan bahwa penelitian kualitatif adalah penelitian yang bermaksud untuk memahami fenomena tentang apa yang dialami oleh subjek penelitian, misalnya perilaku, persepsi, motivasi, tindakan dan lain-lain secara holistik dan dengan cara deskripsi dalam bentuk kata-kata dan bahasa, pada suatu konteks khusus yang alamiah dan dengan memanfaatkan berbagai metode alamiah.

Penegasan di atas, menunjukkan bahwa penelitian kualitatif itu berfokus pada manusia dengan segala kompleksitasnya. Juga memiliki kelebihan untuk menangani berbagai isu dan factor yang tidak mudah diukur, dan dijelaskan dengan cara-cara kuantitatif. Sugiyono (2017:9) menjelaskan bahwa "penelitian kualitatif digunakan untuk meneliti pada kondisi objek yang alamiah. Dimana peneliti sebagai kunci, teknik pengumpulan data secara triangulasi, analisis data bersifat kualitatif. Maka ketika bahan bacaan yang ada juga memiki informasi yang tidak memadai tentang fenomena yang dikaji, kita mesti banyak belajar dari para partisipan melalui eksplor. Peneliti ini berusaha mengeksplor hakikat dari gejala-gejala yang muncul dari subjek penelitian. Hakikat tersebut digunakan untuk mendeskripsikan kemampuan berpikir kritis siswa. Hakikat tersebut ditelusuri menggunakan metode kualitatif.

Menurut Moleong (2017:8) penelitian kualitatif mempunyai ciri-ciri sebagai berikut (1) Mempunyai latar alami; (2) Peneliti sebagai instrument utama; (3) Menggunakan metode kualitatif; (4) Analisis data secara induktif; (5) Teori dari dasar (grounded theory); (6) Bersifat adanya batas yang ditemukan oleh focus penelitian; (7) Lebih mementingkan proses daripada hasil; (8) adanya batas yang ditentukan oleh fokus penelitian; (9) Adanya kriteria untuk untuk keabsahan data; (10) desain penelitian bersifat sementara; (11) hasil penelitian dirundingkan dan disepakati bersama.

\section{Tempat dan Waktu Penelitian}

Lokasi penelitian ini adalah di MAS Al-Washliyah KM.6 Medan T.P. 2020/2021, dengan jadwal yang dikoordinasikan dengan kegiatan sekolah yang akan dilaksanakan pada semester ganjil.

\section{Subjek dan Objek Penelitian}

Pada bagian awal, subjek penelitian ini melibatkan siswa kelas XI-A di MAS Al-Washliyah KM.6 Medan yang diberi perlakuan dengan model pembelajaran Problem Based Learning pada semester genap T.P.2020/2021 yang berjumlah 30 orang. Subjek dalam penelitian ini adalah siswa yang diwawancarai berdasarkan hasil tes kecerdasan logis matematis yang diujikan dan berdasarkan skala self confidence yang diisi oleh siswa. Subjek dipilih melalui kacamata indikator kecerdasan logis matematis dan melalui kacamata indikator self confidence.

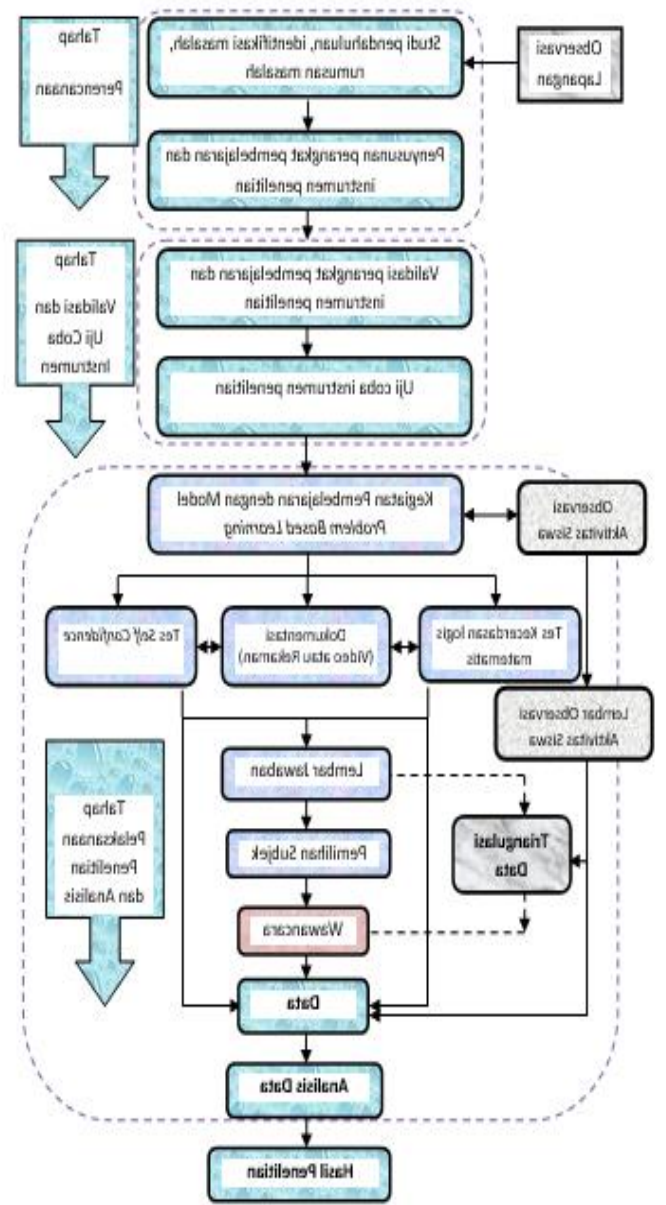

Gambar 1. Proses Penelitian 
Berdasarkan Gambar maka pada rancangan penelitian adapun langkah-langkah penelitian di uraikan sebagai berikut :

1. Observasi Lapangan

Pada akhir November 2020 peneliti melakukan pendekatan (konsultasi) terhadap kepada sekolah, guru kelas mata pelajaran matematika MAS AlWashliyah KM.6 Medan. Kemudian melaksanakan observasi terhadap kegiatan pembelajaran di sekolah tersebut dan melaksanakan penelitian pendahuluan dengan memberi tes kecerdasan logis matematis dan self confidence siswa kelas XI MAS AL-Washliyah Km.6 Medan.

2. Menyusun Proposal Penelitian

Penyusunan proposal penelitian meliputi penyusunan rancangan pelaksanaan penelitian yang meliputi penyusunan Pendahuluan, Kajian Teoritis, Metode Penelitian, Perangkat Pembelajaran dan Instrumen Penelitian disusun dengan terlebih dahulu dikonsultasikan dengan dosen pembimbing tesis.

3. Validasi dan ujicoba terhadap perangkat pembelajaran dan instrument penelitian.

4. Pelaksanaan pembelajaran matematika dengan pembelajaran problem based learning.

5. Pelaksaan Tes Kecerdasan Logis Matematis dan Sakala Self Confidence Siswa.

6. Pelaksaan wawancara sekaligus Triangulasi

Wawancara dilakukan terhadap subjek yang terpilih dengan pertimbangan subjek tersebut dapat memberikan informasi sesuai dengan tujuan penelitian dan wawancara juga dilakukan terhadap guru yang mengajar dalam tahap pelaksanaan penelitian.

7. Analisis data dan temuan hasil penelitian.

Penulisan Laporan

\section{HASIL}

Tujuan dari penelitian ini adalah menganalisis kecerdasan logis matematis dan kepercayaan diri (self confidence) siswa melalui penerapan model problem based learning (PBL) di kelas XI-A Mas Al-Washliyah Km.6 Pulo Brayan Medan. Model problem based learning diterapkan pada kelas penelitian disebabkan sekolah masih menggunakan model pembelajaran konvensional. Kelas penelitian juga belum terbiasa mengerjakan soal-soal latihan kecerdasan logis matematis, maka sebelum dilakukan pengambilan data, kelas dikondisikan pada penerapan soal-soal kecerdasan logis matematis melalui model problem based learning. Penerapan model problem based learning dalam penelitian ini bertujuan untuk membantu siswa merencanakan penyelesaian masalah, sehingga mampu menyelesaikan masalah yang berhubungan dengan kecerdasan logis matematis. Oleh sebab itu, perangkat pembelajaran yang digunakan disusun berdasarkan model problem based learning dan valid berdasarkan validasi ahli. Penelitian ini juga dilakukan dengan menggunakan instrumen penelitian yang valid, reliabel, terdapat daya pembeda dan tingkat kesukaran berdasarkan validasi ahli maupun empiris (perhitungan statistik).

Tes kecerdasan logis matematis siswa diikuti oleh 30 siswa yang telah mengikuti pembelajaran menggunakan model problem based learning. Analisis kecerdasan logis matematis siswa kelas XI-A dilaksanakan dengan menganalisis hasil tes kecerdasan logis matematis siswa dan hasil wawancara. Kecerdasan logis matematis, masing-masing dikategorikan kedalam kemampuan tinggi, sedang ataupun rendah. Subjek yang akan diwawancarai dipilih berdasarkan hasil tes kecerdasan logis matematis siswa yang dominan pada setiap kategori kecerdasan logis matematis siswa.

Analisis data hasil tes kecerdasan logis matematis siswa dan skala kepercayaan diri (self confidence), serta hasil wawancara, dilakukan dengan langkahlangkah analisis data menurut Sugiyono (2016:247) yaitu "pengumpulan data (data collection), reduksi data (data reduction), penyajian data (data display), dan penarikan kesimpulan (conclusion)". Kegiatan pengumpulan data pada penelitian ini yaitu mengumpulkan semua data yang dibutuhkan berupa hasil tes kecerdasan logis matematis dan skala kepercayaan diri (self confidence) siswa yang sesuai dengan subjek yang terpilih, kemudian menuliskan kembali hasil dari kegiatan wawancara yang masih berupa audio kedalam bentuk tulisan untuk memudahkan dalam menganalisis.

Reduksi data pada penelitian ini yaitu menyederhanakan hasil wawancara kedalam susunan yang baik dan membuang beberapa hal yang tidak perlu. Penyajian data dalam penelitian ini meliputi pendeskripsian hasil tes kecerdasan logis matematis dan angket kepercayaan diri (self confidence), serta hasil wawancara. Penarikan kesimpulan pada penelitian ini dilakukan dengan triangulasi antara hasil tes kecerdasan logis matematis dan skala kepercayaan diri (self confidence), serta hasil wawancara.

\section{Pelaksanaan Proses Pembelajaran}

Kegiatan pembelajaran dilaksanakan sebanyak empat kali pertemuan pada kelas XI-A di MAS AlWashliyah KM.6 Pulo Brayan Medan yang berjumlah 30 siswa. Kegiatan di mulai dengan pembelajaran dilaksanakan dengan menggunakan model problem based learning dengan materi program linier, kemudian diberikan tes kecerdasan logis matematis siswa. Pembelajaran menggunakan perangkat pembelajaran yaitu Rencana Perangkat Pembelajaran (RPP) dan Lembar Kegiatan Peserta Didik (LKPD) yang disusun berdasarkan model problem based learning.

Lembar Kegiatan Peserta Didik (LKPD) yang disusun berdasarkan model problem based learning, menuntut siswa untuk menyelesaikan masalah yang ada pada LKPD tersebut dengan berdiskusi dengan teman sekelompoknya dan dibimbing oleh guru hanya seperlunya saja. Selanjutnya siswa akan berdiskusi untuk menyelesaikan semua malasah yang ada pada 
Vol. 14, No. 1, Juni 2021

Lembar Kegiatan Peserta Didik (LKPD). Setelah mereka selesai mengerjakan soal sesuai dengan waktu yang telah ditentukan, maka selanjutnya perwakilan kelompok maju untuk menyajikan hasil diskusi kelompoknya didepan kelas. Adapun jadwal pelaksanaan pembelajaran penelitian yang dilakukan peneliti di MAS Al-Washliyah KM.6 Pulo Brayan Medan pada kelas XI-A dapat dilihat pada Bab III.

\section{Deskripsi Kepercayaan Diri (Self Confidence) Siswa}

Deskripsi kepercayaan diri (self confidence) siswa diperoleh berdasarkan skor setiap masing-masing siswa berdasarkan pengisian skala kepercayaan diri (self confidence). Seluruh lembar jawaban siswa dari hasil angket kepercayaan diri (self confidence) dikumpulkan untuk diperiksa dan diberi skor. Pemberian skor setiap jawaban siswa berdasarkan pada pedoman penskoran skala kepercayaan diri (self confidence).

Berdasarkan perolehan data penelitian yang diperoleh melalui angket kepercayaan diri (self confidence), dapat dilihat pada tabel berikut:

Tabel 2. Hasil Kategori Tingkat Kepercayaan Diri (Self Confidence) Siswa

\begin{tabular}{cccc}
\hline Rentang Skor & Jumlah Siswa & Persentase & Kategori \\
\hline $\bar{X} \geq 66,4$ & 6 & $20,00 \%$ & Tinggi \\
\hline $48,4 \leq \bar{X}<66,4$ & 20 & $66,67 \%$ & Sedang \\
\hline $\bar{X}<48,4$ & 4 & $13,33 \%$ & Rendah \\
\hline Jumlah & 30 & $100 \%$ & \\
\hline
\end{tabular}

Berdasarkan Tabel 4.5 di atas dapat dilihat bahwa terdapat $20 \%$ atau 6 responden yang menunjukkan hasil kepercayaan diri yang tinggi, 66,67\% atau 20 responden yang menunjukkan hasil kepercayaan diri yang sedang, dan $13,33 \%$ atau 4 responden yang menunjukkan hasil kepercayaan diri yang rendah. Jumlah keseluruhan responden adalah 30 responden. Adapun diagram batang kategori kepercayaan diri (self confidence) siswa disajikan pada gambar 4.5.

\section{Kepercayaan Diri (Self Confidence)Siswa}

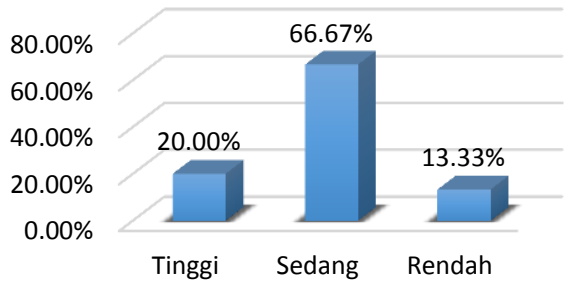

Gambar 2. Diagram Kategori Kepercayaan Diri (Self Confidence) Siswa

\section{Analisis Kesulitan Siswa dalam Menyelesaikan Tes Kecerdasan Logis Matematis}

Analisis kesulitan siswa dalam menyelesaikan tes kecerdasan logis matematis siswa diperoleh dari hasil tes kecerdasan logis matematis siswa dan wawancara yang dikaitkan dengan indikator kesulitan siswa yaitu (1) mempelajari konsep (2) menerapkan keterampilan (3) menyelesaikan pemecahan masalah. Lembar jawaban tes kecerdasan logis matematis setiap siswa dikoreksi berdasarkan pedoman penskoran kecerdasan logis matematis dan dikategorikan kedalam tinggi, sedang, dan rendah. Setiap kategori kecerdasan logis matematistis siswa masing-masing diamati lembar jawabannya untuk menentukan pola-pola jawaban siswa. Kemudian berdasarkan pola tersebut, dipilihlah siswa sebagai subjek yang dianalisis secara kualitatif dengan pola jawaban yang dominan pada setiap kategori.

Berdasarkan hasil tes kecerdasan logis matematis siswa dan telah dikategorikan kedalam kategori kecerdasan logis matematis siswa, maka dari 30 siswa dipilih 1 siswa dengan kemampuan penalaran matematis siswa kategori tinggi, 1 siswa dengan kemampuan penalaran matematis siswa kategori sedang dan 1 siswa dengan kemampuan penalaran matematis siswa kategori rendah sebagai subjek yang dianalisis secara kualitatif.

\section{PEMBAHASAN}

\section{Kepercayaan Diri (Self Confidence) Siswa}

Skala kepercayaan diri (self confidence) siswa diberikan setelah diterapkannya model problem based learning mendapatkan hasil dari 30 siswa terdapat 6 siswa (20\%) yang memiliki kepercayaan diri (self confidence) siswa kategori tinggi, 20 siswa $(66,67 \%)$ yang memiliki kategori sedang, dan 4 siswa $(13,33 \%)$ yang memiliki kategori rendah.

Hasil penelitian ini tidak lebih baik dari hasil penelitian Ibrahim (2018:75) yaitu dari 29 siswa terdapat 21 siswa $(72,41 \%)$ yang memiliki kepercayaan diri (self confidence) siswa kategori tinggi, 6 siswa $(20,69 \%)$ yang memiliki kategori sedang, dan 2 siswa $(6,89 \%)$ yang memiliki kategori rendah.

Terdapat $(52,41 \%)$ selisih siswa yang memiliki kepercayaan diri (self confidence) siswa kategori tinggi. Artinya penelitian ini lebih sedikit memperoleh siswa yang memiliki kepercayaan diri (self confidence) kategori tinggi dibandingkan penelitian Ibrahim.

Terdapat $(45,98 \%)$ selisih siswa yang memiliki kepercayaan diri (self confidence) siswa kategori sedang. Artinya penelitian ini lebih banyak memperoleh siswa yang memiliki kepercayaan diri (self confidence) kategori sedang dibandingkan penelitian Ibrahim.

Terdapat $(6,44 \%)$ selisih siswa yang memiliki kepercayaan diri (self confidence) siswa kategori rendah. Artinya penelitian ini lebih banyak memperoleh siswa yang memiliki kepercayaan diri (self confidence) kategori rendah dibandingkan penelitian Ibrahim.

\section{Kesulitan Siswa dalam Menyelesaikan Tes Kecerdasan Logis Matematis Siswa}

Pada penelitian ini dilakukan analisis kesulitan siswa dalam menyelesaikan tes kecerdasan logis matematis siswa. Kesulitan siswa dalam menyelesaikan tes kecerdasan logis matematis siswa mempunyai tiga indikator yaitu indikator konsep, keterampilan, dan 
pemecahan masalah. Berbeda dengan penelitian yang dilakukan oleh Akbar (2018:14) yang melakukan penelitian analaisis kecerdasan logis matematis namun hanya menganalisis bagaimana peningkatan kecerdasan logis matematis dan setiap indikator kemampuan penalarannya saja.

Siswa dengan kecerdasan logis matematis kategori tinggi dan sedang mengalami kesulitan pada indikator konsep sedangkan siswa dengan kecerdasan logis matematis siswa kategori rendah mengalami kesulitan pada indikator konsep dan pemecahan masalah.

Analisis kesulitan siswa dalam meyelesaikan tes kecerdasan logis matematis siswa pada penelitian diperoleh dari lembar jawaban tes kecerdasan logis matematis dan wawancara. Sedangkan analisis kesulitan siswa yang dilakukan pada penelitian Ario (2016:127) diperoleh dari data tes, wawancara dan hasil observasi.

\section{KESIMPULAN}

Dari hasil analisis dan pembahasan diperoleh kesimpulan sebagai berikut :

1. Kepercayaan diri (self confidence) siswa setelah diterapkan model problem based learning didapat bahwa dari 30 siswa terdapat 6 siswa yang memiliki kepercayaan diri (self confidence) kategori tinggi, 20 siswa yang memiliki kategori sedang, dan 4 siswa yang memiliki kategori rendah.

2. Kesulitan siswa dalam menyelesaikan tes kecerdasan logis matematis siswa, sebagai berikut :

a. Pada kategori tinggi dan sedang, siswa mengalami kesulitan pada indikator konsep.

b. Pada kategori rendah, siswa mengalami kesulitan pada indikator konsep dan pemecahan masalah.

\section{REFERENSI}

Abdurrahman, M. 2009. Pendidikan Bagi Anak Berkesulitan Belajar. Jakarta: Rineka Cipta.

Aisyah, P. N., dkk. 2018. Analisis Hubungan Kemampuan Pemecahan Masalah Matematis dan Self-Confidence Siswa SMP. Journal on Education, Volume 1, No.1, Desember 2018, pp 58-65. E-ISSN 2654-5497, P-ISSN 2655-1365.

Akbar, G. A. M. dkk. 2018. Analisis Kecerdasan Logis Matematis dan Self Confidence Siswa SMA dalam Materi Peluang. Journal On Education. Vol. 1, No. 1.

Aman, D. 2018. Pengaruh Pembelajaran Berbasis Masalah Menggunakan Software Autograph terhadap Peningkatan Kemampuan Representasi Matematik dan Motivasi Belajar Siswa SMK Negeri 4 Tanjung Balai. Tesis tidak diterbitkan. Medan: Program Pascasarjana UNIMED Medan.

Arend, R. I. 2008b. Learning To Teach. Buku Kedua, Edisi Ketujuh. Yogyakarta: Pustaka Pelajar.

Arikunto, S. 2012. Dasar-dasar Evaluasi Pendidikan. Jakarta: PT Bumi Aksara

Ario, Marfi. 2016. Analisis Kecerdasan Logis Matematis Siswa SMK setelah Mengikuti
Pembelajaran Berbasis Masalah. Jurnal Ilmiah Edu

Research, Vol. 5, No.2

Armstrong, T. 1999. Kecerdasan Multipel di Dalam Kelas. Jakarta : Indeks.

Astutik, H. S \& Aniningsih, P. 2019. Efektifitas Pembelejaran Problem Based Learning Berbantuan Virtual Laboratory Ditinjau Dari Hasil Belajar Dan Kemampuan Berpikir Logis Matematis Siswa SMP. Journal of Honai Math, Vol 2. No 1 pp 25-36, April 2019, p-ISSN: 2615-2185. E-ISSN: 26152193.

Aulia, Kharisma. 2018. Analisis Kesalahan Siswa Dalam Menyelesaikan Soal Cerita Materi Segiempat Berdasarkan Newman's Error Analysis (NEA) Ditinjau dari Kecerdasan Logis Matematis Siswa. Metadata Citation and Similar Papers at Cove.ac.uk. Vol. 9, No.1 hal 106-115, April 2018.

Biyarti, T. 2013. Eksperimen Model Pembelajaran Think Pair Share Dengan Pendekatan Kontekstual Pada Materi Logaritma Ditinjau Dari Kecerdasan Matematis Logis Siswa Kelas X Pada Sekolah Menengah Atas di Kabupaten Cilacap Tahun Ajaran 2012/2013. Jurnal Elektronik Pembelajaran Matematika, Vol. 1 No. 7 hal 690-699, Desember 2013. ISSN: 2339-1685. http: //JurnalPasca.uns.ac.id

Boity, dkk. 2016. The Implementation Of Problem Based Learning (PBL) In A Year 9 Mathematics Clasroom: A Study In Brunei Darussalam. Internasional Research In Education. Vol. 4 No. 2. ISSN: 2327-5499.

Budiningsih, C. Asri. 2005. Belajan dan Pembelajaran. Jakarta: Rineka Cipta.

Case, L. P., Harris, K.R., \& Graham, S. 1992. Improving The Mathematical Problem-Solving Skills of Students With Learning Disabilities: SelfRegulated Strategy Development. The Journal of Special Education, 26(1), 1-19.

Campbell, Linda, dkk. 2006. Metode Praktis Pembelajaran Berbasis Multiple Intelligences. Depok: Intuisi Press.

Centea, D., Srinivasan, S. 2017. Problem Based Learning In The Conceptual Design Of Hybrid Electric Vehicles. Mc Master University, Canada.

Chatib. M. 2012. Gurunya Manusia: Menjadikan Semua Anak Istimewa dan Semua Anak Juara. Bandung: Kaifa

Chen, H. W. 2013. Applying Problem Based Learning Model And Creative Design To Conic Sections Teaching. Internasional Journal Of Education And Information Technologies. Vol. 7 No. 3.

Dahar, R. W. 2011. Teori-teori Belajar dan Pembelajaran. Jakarta: Erlangga.

Darjiani, Yuni. 2016. Analisis Kesulitan-Kesulitan Belajar Matematika Siswa Kelas V Dalam Implementasi Kurikulum 2013 di SD Piloting SeKabupaten Gianyar Tahun Pelajaran 2015/2016. EJournal PGSD Universtias Pendidikan Ganesha Jurusan PGSD. Vol.3, No.1. 
Vol. 14, No. 1, Juni 2021

Depdiknas. 2003. Undang-Undang No. 20 tahun 2003 Tentang Sistem Pendidikan Nasional. Jakarta; Depdiknas.

2006. Permendiknas Nomor 22 tahun 2006

Tentang Standar Isi Sekolah Menengah Atas. Jakarta: Depdiknas.

2007. Panduan Pengembangan Materi Pembelajaran. Jakarta: Depdiknas Direktorat Jenderal Manajemen Pendidikan Dasar dan Menengah Direktorat Pembinaan Sekolah Menengah Atas.

Dianti, A., Noer, S. H., Gunowibowo, P. 2018. Pengaruh Problem Based Learning Terhadap Kemampuan Berpikir Reflektif Matematis dan Self Confidence. Jurnal Pendidikan Matematika Unila. Volume 6, Nomor 5, Juni 2018. Halaman 332, ISSN:2338-1183

Eviyanti, C. Y. 2017. Improving The Student's Mathematical Problem Solving Ability By Applying Problem Based Learning Model In VII Grade At SMPN 1 Banda Aceh, Indonesia. Internasional Journal of Novel Research In Education And Learning. Vol. 4, Issue 2. PP: (138144), Month: March-April 2017. Available At: www.noveltjournals.com.

Fisher, A. 2007. Berpikir Kritis Sebuah Pengantar (Critical Thinking An Introcduction). Terjemahan Oleh Benyamin Hadinata, 2008. Jakarta: Erlangga.

Gardner, H. 2003. Multiple Intelligences. Jakarta: Darabooks.

Gooding, S. 2009. Childern's Difficulties With Mathematical Word Problems. University of Cambridge, UK. Joobert $M(E d)$. Proceeding of The British Society for Research Into Learning Mathematics, 29(3).

Harahap, E. R., Surya, E. 2017. Kemampuan Pemecahan Masalah Matematis Siswa Kelas VII Dalam Menyelesaikan Persamaan Linier Satu Variabel. SEMNASTIKA UNIMED. ISBN;978-60217980-9-6.

Hasratuddin. 2018. Mengapa Harus Belajar Matematika. Medan: Perc Edira

Hidayat, Wahyu. 2013. Mengembangkan Kemampuan Komunikasi dan Berpikir Logis Serta Disposisi Matematik Siswa SMA Melalui Pembelajaran Berbasis Masalah. Prosiding Seminar Nasional,Volume 1, Tahun 2013. ISSN: 9772338831.

Ibrahim, Malik. 2018. Peningkatan Kepercayaan Diri Siswa Terhadap Matematika Dengan Menggunakan Model Problem Based Learning (PBL). Jurnal Pemikiran dan Penelitian Pendidikan. Vol.16, No.1, Juni 2018. ISSN:1829-5940, ISSN:25034510

Indah, A., Lestari, dkk. 2019. Modifikasi Pendekatan Pembelajaran Matematika Realistik dengan Strategi Pembelajaran Tugas dan Paksa. Prosiding Seminar Nasional Pendidikan KALUNI, Vol. 2

Istiawti, S. N. 2017. Pengaruh Model Problem Based Learning Berbantuan Macromedia Flash Terhadap
Kemampuan Representasi Matematis dan Self Confidence Siswa Kelas VII SMPN 1 Sidamanik. Tersedia: http://digilib.unimde.ac.id.

Kemendikbud. 2013. Kerangka Dasar dan Struktur Kurikulum 2013. Jakarta; Kemendikbud.

2016. Kemendikbud Rilis Hasil Ujian

Nasional Perbaikan. Jakarta: Biro Komunikasi dan layanan Masyarakat, Kemendikbud.

Khaerunisa, F. 2012. Penerapan Better Teacing and Learning Berbasis Pembelajaran Kooperatif untuk Meningkatkan Berpikir Logis dan Keaktifan Siswa. Unnes Physics Education Journal (Vol.1, No. 2, November/2012), hlm. 35.

Kolb, D. A. 2015. Experiental Learning: Experiental As The Source Of Learning And Development. Second Edn. Pearson Education.

Librianti, Vinny, dkk. 2015. Kecerdasan Visual Spasial dan Logis Matematis Dalam Menyelesaikan Masalah Geometri Siswa Kelas VIII A SMP Negeri 10 Jember (Visual spatial adn Logical Mathematical Intellegence in Solving Geometry Problem Class VIII A SMP Negeri 10 Jember). Artikel Ilmiah Mahasiswa, 2015. 1(1):1-7

Lwin, May, dkk. 2008. How to Multiply Your Child's Intelligence. Yogyakarta: Indeks.

Maghfiroh Titin. 2019. Pengaruh Kecerdasan Logis Matematis dan Gaya Belajar Terhadap Hasil Belajar Matematika Siswa Kelas XI MIPA SMA N 1 Tengaran Kabupaten Semarang Tahun Pelajaran 2019/2020. Artikel Ilmiah Mahasiswa, 2019.

Meliala, A. 2004. Anak Ajaib: Temukan dan Kembangkan Keajaiban Anak Anda Melalui Kecerdasan Majemuk. Yogyakarta: Andi.

Minarni, A. 2013. Pengaruh Pembelajaran Berbasis Masalah Terhadap kemampuan Pemahaman Matematis dan Keterampilan Sosial Siswa SMP. Perpustakaan.upi.ed | repository.upi.edu

Moleong, L, 2017. Metodologi Penelitian Kualitatif, Penerbit: PT Remaja Rosdakarya

Mukaromah, Gunowibowo, P., Coesamin, M., 2018. Pengaruh Problem Based Learning Terhadap Kemampuan Komunikasi Matematis Dan Self Confidence Siswa. Jurnal Pendidikan Matematika Unila, Volume 6, Nomor 1, Maret 2018, Halaman 101, ISSN: 2338-1183.

Muniro, S., Rosyana, T., Hendriana, H. 2018. Hubungan Self Confidence Dengan Kemampuan Komunikasi Matematika Siswa SMP. JPMI, Volume 1. No.4, Juli 2018, pp 479-486. ISSN 264221, ISSN 264-2155.

Napitupulu, E.E., 2011. Pengaruh Pembelajaran Berbasis Masalah atas Kemampuan Penalaran dan Pemecahan Masalah, serta sikap terhadap Matematika Siswa Sekolah Menengah Atas. Bandung: Disertasi UPI

Ngalimun. (2013). Strategi dan Model Pembelajaran. Yogyakarta: Aswaja Pressindo.

Nisa,Faridah. 2020. Analisis Kecerdasan Logis Matematis dan Kemampuan Komunikasi Matematis Siswa. Alifmatika: Jurnal Pendidikan dan 
Pembelajaran Matematika. Vol.2, No.2. Desember 2020, hal 199-211.

Novferma, N. 2016. Analisis Kesulitan dan SelfEfficacy Siswa SMP Dalam Pemecahan Masalah Matematika Berbentu Soal Cerita. Jurnal Riset Matematika. 3(1):76-87.

Novitasari, D. 2016. Pengaruh Model Discovering Learning Pada Materi Trigonometri Terhadap Kecerdasan Logis Matematis Siswa Kelas X SMA Negeri 2 Salatiga. Tesis tidak diterbitkan. Salatiga: Universitas Kristen Satya.

Nurdin, S. \& Adriatoni. 2016. Kurikulum dan Pembelajaran. Jakarta: PT. Raja Grafindo Persada. ISBN: 978-979-769-956-7.

OECD. 2018. PISA 2018 Results in Focus What 15year-olds know and what they can do with what they know. Tersedia: http://www.oecd.org.

Pehkonen, Erkki. 2007. Problem Solving In Mathematics Education in Finland. Finlandia: University of Helsinki.

Pehkonen, E., Naveri, L., \& Laine, A. 2013. OnTeaching Problem-Solving In School Mathematics. CEPS Journal; Center for Educational Policy Studies Journal, 3(4), 9-23.

Polya, G. 1973. How To Solve It. New Jersey: Princeton University Press.

Purwanto, Ngalim. 2013. Psikologi Pendidikan. Bandung: PT. Remaja Rosdakarya.

Purwasih. R. 2015. Peningkatan Kemampuan Pemceahan Matematis dan Self Confidence Siswa MTs di Kota Cimahi Melalui Model Pembelajaran Inkuiri Terbimbing. Jurnal Ilmiah STKIP Siliwangi Bandung. Volume 9, No.1, Maret 2015. ISSN 1978-5089.

Putra,m P. S. A., \& Wardika, I. W. A. 2019. Pengaruh Model Pembelajaran Problem Based Learning (PBL) Berbantuan Asesmen Kinerja Terhadap Keterampilan Berpikir Kritis Ditinjau Dari Kecerdasan Logis Matematis Mahasiswa. Media Education, Volume 3, Nomor 2, Desember 2019. ISSN: 2580-3344

Raehana. 2019. Pengaruh Kecerdasan Logis Matematis Terhadap Hasil Belajar Matematika Dasar. J.Pijar MIPA. Vol.14, No.3, September 2019, hal 112-117. ISSN:1907-1744, ISSN:2460-1500.

Rusman. 2011. Model-model Pembelajaran Mengembangkan Profesionalisme guru. Jakarta: Rajawali Press.

2012. Model-model Pembelajaran Mengembangkan Profesionalisme guru. Jakarta: Raja Grafindo Persada. ISBN: 978-979-769-460-9

Sagala, S. 2008. Konsep dan Makna Pembelajaran. Bandung: Alfabeta.

Saifullah. 2004. Mencerdaskan Anak (Mengoptimalkan Kecerdasan Intelektual, Emosi dan Spiritual Anak). Jombang: Lintas Media.

Sanjays, W. 2006. Strategi Pembelajaran. Jakarta: Kencana Prenada Media Group.

Seifi, M., Haghverdi, M., \& Azizmohamadi, F. 2012. Recognition of Students Difficulties in Solving
Mathematical Word Problems From The Viewpoint of Teacher. Journal of Basic and Applied Scientific Research, 2(3), 2923-2928.

Sidik, A., Ramlah, \& Utami, M. R. 2017. Hubungan Antara Self-Confidence dengan Kemampuan Komunikasi Matematis Siswa SMP. Prosiding Seminar Nasional Matematika Dan Pendidikan Matematika (SESIOMADIKA), 222-226.

Simamora, R. 2014. Pengembangan Perangkat Pembelajaran dan Penilaian Otentik Melalui Penerapan Model PBM Untuk Meningkatkan Kemampuan Komunikasi Matematis Pada Pokok Bahasan Persamaan dan Pertidaksamaan Linier Satu Variabel di Kelas VII SMP Negeri 1 Siantar. Tesis tidak diterbitkan. Medan: Program Pascasarjana Unimed.

Simatupang, R. 2019. Analisis Kemampuan Pemcehan Masalah Matematis dan Self-Efficacy Siswa Pada Pembelajaran Problem-Based Learning. Terssedia: http://http.digilib.unimed.ac.id.

Simmers, M.J. 2011. It's Not The Math They Hate. Proceedings of International Conference on Mathematics and Engineering HUIC. Hawaii university.

Soedjadi, R. 2000. Kiat Pendidikan Matematika di Indonesia. Jakarta: Direktorat Jenderal Pendidikan Tinggi Departemen Pendidikan Nasional

Sugiyono. 2016. Metode Penelitian Kualitatif Kuantitatif dan $R \& D$. Bandung: Alfabeta 2017. Metode Penelitian Kualitatif Kuantitatif dan $R \& D$. Bandung: Alfabeta

Suhendri, Huri. 2017. Pengaruh Kecerdasan Matematis-Logis dan Kemandirian Belajar Terhadap Hasil Belajar Matematika. Jurnal Formatif 1 (1): 29-39. ISSN: 2088-351x.

Sumarmo, U. 2013. Alternatif Pembelajaran Matematika Dalam Menerapkan Kurikulum Berbasis Komputer (KBK). Bandung: UPI Bandung.

Sundari. 2016. Meningkatkan Hasil Belajar Siswa dalam Pembelajaran Matematika melalui Pendekatan Savi pada Siswa Kelas VB SDIT AlIzzah Sorong. Jurnal Ilmu Kependidikan, Vol. 5, No. 2

Surya, E., Putri, F. A., \& Mukhtar. 2017. Improving Mathematical Problem-Solving Ability and SelConfidence of High School Students Through Contextual Learning Model. Journal on Mathematics Education Vol 8, No1, january 2017.pp 85-99. ISSN 2087-8885, e-ISSN 24070610.

Torp, L., Saga, S. 2002. Problem As Possibilities Problem Based Learning For K-16 Education. 2nd Edition. Association For Supervision And Curriculum Development. Alexandria: Virginia USA.

Tresnawati, Hidayat, W., \& Rohaeti, E. E. 2017. Kemampuan Berpikir Kritis Matematis dan Kepercayaan Diri Siswa SMA Pasundan. Journal of 
Vol. 14, No. 1, Juni 2021

Research in Mathemathics Learning and
Education, 2(2), 116-122

Trianto. 2011. Mendesain Model Pembelajaran Inovatif-progresif. Jakarta: Kencana.

Ulfah, Farida. 2017. Penerapan Model Problem Based Learning (PBL) Dengan LKS Untuk Meningkatkan Kemampuan Berpikir Kritis dan Logis. Jurnal Derivat. Vol. 1, No. 1, Juli 2017,hal $35-43$

UNDP. 2019. Human Development Reports 2019. Tersedia: http://hdr.undp.org.

Wardani, S. 2008. Analisis SI dan SKL Mata Pelajaran Matematika SMP/MTs untuk Optimalisasi Tujuan Mata Pelajaran Matematika. Yogyakarta: Pusat Pengembangan Dan Pemberdayaan Pendidik Dan Tenaga Kependidikan Matematika.
Wirasti, N. K. 2016. Pengaruh Penerapan Model Pembeljaran Pemecahan Masalah Berorientasi Masalah Matematika Terbuka Terhadap Kemampuan Pemecahan Masalah Ditinjau Dari Kecerdasan Logis Matematis Siswa Kelas X SMA Negeri 2 Denpasar. Prosiding Seminar Nasional MIPA, 2016. ISBN: 978-602-6428-004.

Wulandari, \& NJM Sinambela. 2017. Hubungan Kepercayaan diri (Self Confidence) dengan Kemampuan Pemecahan Masalah Matematika Siswa dengan Menggunakan Model Problem Based Learning di MAN Kisaran. Jurnal Inspiratif, Vol. 3 No. 2 Agustus 2017. p-ISSN: 2442-8876, e-ISSN: 2528-0475. 